\title{
ROSALIND BROWN-GRANT, Perspectives sur la guerre: l'apport textuel et visuel des romans en prose bourguignons
}

\section{Maria Colombo Timelli}

\section{(2) OpenEdition}

\section{Journals}

\section{Édition électronique}

URL : https://journals.openedition.org/studifrancesi/44809

DOI : 10.4000/studifrancesi.44809

ISSN : 2421-5856

Éditeur

Rosenberg \& Sellier

\section{Édition imprimée}

Date de publication : 1 août 2021

Pagination : 355-356

ISSN : 0039-2944

\section{Référence électronique}

Maria Colombo Timelli, « Rosalind Brown-grant, Perspectives sur la guerre: l'apport textuel et visuel des romans en prose bourguignons », Studi Francesi [En ligne], 194 (LXV | II) | 2021, mis en ligne le 06 septembre 2021, consulté le 15 octobre 2022. URL : http://journals.openedition.org/studifrancesi/ 44809 ; DOI : https://doi.org/10.4000/studifrancesi.44809

Ce document a été généré automatiquement le 15 octobre 2022.

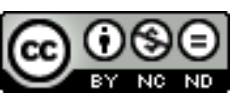

Creative Commons - Attribution - Pas d'Utilisation Commerciale - Pas de Modification 4.0 International - CC BY-NC-ND 4.0

https://creativecommons.org/licenses/by-nc-nd/4.0/ 


\title{
ROSALIND BROWN-GRANT, Perspectives sur la guerre: l'apport textuel et visuel des romans en prose bourguignons
}

\author{
Maria Colombo Timelli
}

\section{RÉFÉRENCE}

ROSALIND BROWN-GRANT, Perspectives sur la guerre: l'apport textuel et visuel des romans en prose bourguignons, "Le Moyen Âge”, CXXV, 2019/1, pp. 111-128.

1 La littérature narrative «bourguignonne» produite, en gros, sous Philippe le Bon, constitue un corpus à la fois homogène et représentatif des goûts et des mentalités de la haute noblesse $d u x^{e}$ siècle. R. B.-G. en donne un exemple à partir d'un texte paradigmatique, l'Histoire des Seigneurs de Grave, dont le manuscrit unique, illustré par le «Maître de Wavrin», est conservé à la KBR de Bruxelles, sous la cote 10238. Elle montre d'abord combien l'interrogation sur la justesse du combat - guerre ou duel judiciaire est fondamentale dans le portrait du héros, puis comment les enluminures qui accompagnent le récit confirment-par des traits sémiques récurrents et reconnaissables - son rôle de garant de la justice, publique et privée, et finalement de garant de la paix. 